\title{
Finnish Migration and the European Integration Process
}

\author{
ISMO SÖDERLING
}

Research Secretary, Docent

Institute of Migration

\section{Introduction}

Population questions have emerged as important social policy issues of the 1990s in Finland. Our strict immigration and refugee policy, the need for foreign labor caused by the labor shortage and Europe's development toward integration have been central elements of the discussion, which has been under way.

The debate concerning integration, in particular, is widening and becoming more diversified day by day. On the other hand, the discussion taking place in Finland is based more on assumptions than on research findings, for our country still lacks the basic studies illuminating the subject. In this respect, however, a decided improvement will take place in the next few years, for the Academy of Finland, for example, in the beginning of 1990, named research on integration in Europe as one of its main areas of emphasis. These measures are, perhaps, a little late in coming, for our country must make significant social policy decisions concerning integration by the end of 1992.

The concept of integration is used in many fields of science to describe various processes of unification and assimilation as one functional entity. The term came into general use in the 1950s. At that time, the concept of integration was beginning to be used to describe the economic policy between nations; in this context, integration means a continuous, conscious striving toward the formation of social, national or supranational entities.

Usually integration is understood as economic cooperation between nations. Because it is difficult to draw a clear line between economic and other legislation, economic integration easily leads to political integration and vice versa.

Currently, integration is primarily used to signify the development taking place within the European Community (EC). In regard to Finland, however, we must remember that our membership in EFTA and in the common Nordic labor market is part of the integration policy already begun earlier by our country.

\section{The integration policy of the European Community}

In June 1985, the EC Commission submitted a so-called »White Paper», a program for creating a free internal market. The book proposes that an internal market be realized by the end of 1992 . The goal is to create a common internal market, where there are no limits to the flow of goods and no barriers erected to the free mobility of people, services and capital. There are now 12 countries belonging to the European Community.

In the EC, the mobility of the population is seen as an important prerequisite to the economic development of the Community. In the Community, freedom of 
movement is quite a limited concept: it mainly concerns seeking work in another member State. If the jobseeker does not find employment within three months, his or her residence permit will expire. If the migrant does find employment, then, in the normal case, the residence permit must be granted for five years. If, however, the employment is for less than one year, the residence permit is granted for one year. Even if granting a residence permit for internal migration within the EC is practically automatic, it is also one means of controlling mobility. (Muistio 15.9. 1989/TT)

The European Community is thus not a passport union and area of totally free mobility like the Nordic Countries. The right to move freely within the Nordic Countries is founded on the traditional »everyman's right»: according to this right, an individual is seen as having the right to live wherever he or she wants in the Nordic Countries. The common Nordic labor market is conceptually quite limited, however, for the »reservation» of central public offices and positions for the country's own citizens has made movement between the Nordic Countries mainly a migration of non-white-collar workers. In this respect, the aims and practices of the EC are more impartial. (Andersen 1988, 9)

\section{Finland's integration alternatives}

Earlier, it was noted that a central aim of integration is to promote the economic development of member States. Finland, naturally, wants to maintain its ability to compete internationally and, therefore, to take part in the integration process.

The Commission of the European Community had a broad study made on the effects of a common market, which is known as the Cecchini Report (1988). The report assesses the micro and macro level effects of integration on the basis of a broad survey covering over 20,000 enterprises and by using a separate model. According to the Cecchini Report, the realization of a common market will have very positive total economic effects - at least, in the medium and long term, after difficulties at the outset. (Parviainen 1989, 34-35). The realization of the internal market will, it is hoped, boost economic growth and employment prospects in the Community. The Cecchini Report estimated that the abolition of non-tariff barriers could reduce costs considerably and boost growth by $3-6 \%$, with perhaps 1.8 million additional jobs over six years (ILO 1989, 3).

Some estimates have been made in Finland, also, of the possible economic consequences of integration. According to Lahti (1989), it has been assumed that forming closer ties with the EC will benefit Finland's national economy, so that the gross national product would grow about 2.7 percent more in the next nine years compared to a continuation of the present situation. In addition, exports would increase about $7 \%$ more during the period in question (see Lumijärvi 1990, 51).

The economic benefits of integration are, thus, indisputable. Finland is not applying for regular membership in the EC, however, on the plea of Finland's neutrality. EFTA and the European Community together accepted in 1984 the so-called Luxemburg Declaration, which will lead to the formation of an 18-nation European economic region or the EES (European Economic Space; see Valtioneuvoston tiedonanto... 1989, 5-6). It is probable that Finland, as an EES member, will commit itself to the general development toward integration: only foreign and security policy decision making will remain outside integration development. 


\section{The relations between integration and migration}

Large mass migrations do not arise without the simultaneous appearance of pushing factors in the country of departure and pulling factors in the country of arrival. For example, Finland's unemployment and the "population surplus» of the large age groups occurred in the 1960s at the same time as Sweden's large labor shortage. The factors triggering migration included Finland's currency devaluation in 1967 (and the sillusion of money» it created), the recruiting of workers by the Swedes and mass decisions to migrate. The push-pull theory is, in its simplicity, a rather functional one in explaining large migration flows.

In 1985, five million citizens of other member States lived in the EC. About onehalf of them were employed. The number of migrants from outside the EC countries in the EC member States was then about seven million (Nordisk Ministerråds Sekretariat, Nov. 1988, 9). Only $1.5 \%$ of the labor force of the Community's member States is from another Community State (Valtioneuvoston tiedonanto Eduskunnalle..., 1989, 19).

Table 1. Estimate of the number of non-nationals who are documented or in a regular situation residing and working in EC member States.

$\begin{array}{lcccc}\text { Country } & \text { Year } & \begin{array}{c}\text { Resident } \\ \text { Non-nationals }\end{array} & \begin{array}{c}\text { of which from } \\ \text { EC Countries }\end{array} & \begin{array}{c}\text { Percentage of } \\ \text { Non-EC nationals }\end{array} \\ \text { Belgium } & 1987 & 853000 & 538000 & 36.9 \\ \text { Denmark } & 1987 & 128000 & 27000 & 78.9 \\ \text { France } & 1982 & 3680000 & 1578000 & 57.1 \\ \text { Germany } & 1987 & 4630000 & 1378000 & 70.2 \\ \text { Greece } & 1987 & 193000 & 111000 & 42.5 \\ \text { Ireland } & 1985 & 88000 & 67000 & 23.9 \\ \text { Italy } & 1987 & 541000 & 150000 & 72.3 \\ \text { Luxemburg } & 1981 & 96000 & 89000 & 7.3 \\ \text { Netherlands } & 1987 & 568000 & 160000 & 71.8 \\ \text { Portugal } & 1987 & 90000 & 24000 & 73.3 \\ \text { Spain } & 1987 & 335000 & 194000 & 42.1 \\ \text { United K. } & 1986 & 1736000 & 754000 & 56.6 \\ \text { EC } & & 12938000 & 5070000 & 60.8\end{array}$

Source: ILO 1989: Regular Budget Technical Co-operation Programme, p. 31.

On the basis of the above, it is justified to assume that Finland's integration into the EC's free labor market will not signify a large migration into our country. Straubhaar has studied the migration between the predecessors of the current twelve EC countries, the Europe Six (EC6). His results can be generalized to today's movement situation. His central observation is that within the EC migration occurs within adjacent areas, for example, as migration between the Benelux countries.

The legal liberalization of the labour movements did not significantly stimulate intra EC6 migration flows, compared to the migration flows from outside the common labour market into the EC6. Mobility among the EC6 members has hardly increased since the formation of the common labour market;

Despite the fears of the immigration countries (especially France), the formation of the common labour market did not induce a strong movement of workers moving from low (especially Italy) to high income countries. The migration flows from Italy to the other EC6 members increased, but more slowly than the flows from other Southern European countries not members of the EC6. (Straubhaar 1987, 12) 
For the European Community, its three newest countries, Greece, Spain and Portugal, pose an open question, to some extent. Greece was permitted free migration in the EC in 1989; Spain and Portugal will be allowed the right to free labor mobility at the beginning of 1993. According to a report made by the International Labor Organization (ILO), Greece and Portugal do not form a substantial potential area of departure for migration. Greece is relatively out-of-the-way and Spain, again, already experienced its largest out-migration about twenty years ago. Portugal may be a labor-yielding country after 1993 . According to the report, migration will probably be directed mainly toward France, where there is already a large Portuguese minority (ILO 1989, 5-7; see also Straubhaar 1984, 235).

According to Straubhaar $(1987,12)$, there are three reasons why integration will not stimulate migration between the Community States.

1. Individual, social, cultural and linguistic differences will remain between the countries, despite the disappearance of the formal barriers to migration.

2. The barriers preventing trade in the market area will disappear more easily than those preventing migration. It will be easier to move products and the means of production than labor.

3. The market will make the member States similar in regard to their national economy. There will then be no great need to relocate production and the labor force.

In addition to the above, one factor preventing mobility is the rising social security in the EC countries. Improvements in unemployment security will probably mean that people will prefer to suffer unemployment in their own country, rather than seek employment in some other country. Even high unemployment in member States of the Community has not led to large mass migration.

\section{Integration and the pressure toward migration to Finland}

It was noted earlier that, on the average, only about $1.5 \%$ of the labor force of the member States is from some other member State. It was also noted that, of all the migrants in the EC States, only $40 \%$ are from another member State of the Community. Denmark is now the only Nordic member State in the Community. The immigration from the EC into Denmark is clearly less than the average, for, in 1986, Denmark had about 27,000 immigrants from other EC countries. Of these, 12,000 were members of the labor force, or $0.6 \%$ of Denmark's labor force (see ILO 1989, $31-32)$.

On the basis of the above, it is quite justified to assume that Finland's integration into the EC's free labor market will not signify a large migration into our country. The labor markets of the Federal Republic of Germany, Denmark and especially Sweden form an effective buffer zone against EC migration pressure directed toward Finland. If we use Denmark's migration figures as a base, it is presumable that, after integration, migration from the EC countries to Finland will increase yearly by a few hundred persons. The demographic background of the migrants and the motives for their migration are difficult to predict at this time. It is apparent that the serenity and vast reaches of nature in Finland attract migrants here from Central Europe's crowded areas, who come here particularly because they want to raise the quality of their lives. The number of people arriving for this reason is apparently small. »Back-to-nature»-migration has all the more curiosity and publicity value.

Sweden has also concluded that, in the future, there will be no great pressure toward migration from the EC States:

»Despite the removal of internal barriers to migration within the EC, mo- 
bility has actually decreased in the 1970 s and the 1980 s in countries belonging to the free labor market...

...but when countries like Spain and Portugal join the free labor market in 1993, the figures showing mobility in the EC area will be completely different. The Portuguese, especially, are very willing to work abroad.

The distance factor is, of course, an important factor in migration pressure toward Sweden. It must be remembered that Sweden lies very far from the real low-wage countries of the EC, Greece, Spain and Portugal. The citizens of these three countries living abroad are concentrated much more in countries which are Sweden's competitors, so that Sweden's possibilities to recruit labor more easily in the future must be considered unlikely.» (Lundborg 1989, $1,9-10)$

The EC's internal development favors the migration of trained labor. This is a consequence of the internationalization of entrepreneurial and training activity (cf. e.g. corporate in-house migration). Apparently, Central Europe will be increasingly an alternative for the migration of highly trained people from Finland to Sweden or to the United States. These moves are usually for a specific length of time, so that their increase will, of course, also benefit Finland in time. Quantitatively, moves to the EC countries will probably increase by a few hundred a year.

According to Parviainen $(1989,63)$, the danger exists that the Community's labor market will become segmented, so that a highly mobile market will arise for workers who are highly trained and proficient in languages. It is readily apparent that there will be a continuous overdemand for trained labor. On the other hand, there will be a marked decrease of jobs employing the untrained and unskilled. In order to have this kind of work done, the enterprises in the EC countries are now already moving their work-intensive production to countries with cheap labor, especially to the Far East.

\section{Where will migrants to Finland come from?}

Finland now has about 55,000 foreign-born inhabitants. Perhaps one-third of these are of Finnish descent, migrants returning from abroad. There are 18,500 foreign citizens living in Finland. As a whole, the foreign population living in Finland is small. Nevertheless, there is growing pressure toward migration to Finland. The reasons related to this include the following:

1. The labor shortage is a fact, especially in the Helsinki metropolitan area. According to a forecast made by the Ministry of Labor, the demand for labor will grow annually in the 1990 s by 7,000 persons, but the labor supply by only 3,500 persons. In ten years the labor shortage will thus increase by 35,000 persons. (Työministeriö $1988,4-5)$

2. The percentage of elderly people is steadily increasing. Population development will reach its peak at the turn of the century. When the large age groups born after the war become receding age groups, our country's population will begin a strong decline. This presumes that the birth rate and migration will stay at the current level. In this regard, there are now about 4.95 million inhabitants in Finland, of whom $12 \%$ are over 64 years of age. In 2030 the corresponding figures will be 4.69 million and $24 \%$. In 2050 the population of our country is predicted to drop under four million (EVA 1988, 9). Economic development demands dynamism and creativity from the labor market's labor force. It is difficult to cause a rise in the birth rate in the 
Western countries, so that if our country wants to participate in international economic competition, this will probably require favoring immigration.

3. Internationalization does not mean opening doors in only one direction, away from Finland. Finland must also reciprocate and open its doors to those desiring to come in. In this respect, the integration policy of the European Community will cause some migration to Finland. Another consequence of internationalization will be the increasing numbers of refugees, especially asylum seekers, at our borders in the next few years. It is probable that the number of quota refugees and those granted asylum will, in the future, total several thousand persons a year.

The skewing population development in our country and the weakening of our economic competitive ability due to the labor shortage are the main reasons for increasing immigration into Finland. The basic question, then, is where these immigrants will be coming from.

It was noted earlier that large mass migrations require the simultaneous existence of pushing factors in the areas of departure and pulling factors in the areas of arrival. According to Mollen and van Mourik, the mobility of labor between various nations is explained, above all, by distance (the closer the areas, the larger the migration) and by income differences (Molle and van Mourik 1988, 336). On this basis, it can be assumed that the largest immigration pressure toward Finland will, in the future, come from the Soviet Union and Poland. Finnish-Swedes are beyond reach because of their age and because they have put down roots. They have formed a permanent Finnish minority in Sweden, numbering over 300,000 persons; the minority's desire and possibilities for returning are decreasing constantly.

In both of our eastern neighboring countries, the current social situation favors large migration: in both the USSR and Poland large internal migrations are yet to come (cf. Finland's rural depopulation process in the 1960s). Part of this kind of internal structural change in a country is always channeled into migration. On the other hand, the nominal wage level in Finland is many dozens of times that of the countries in question, and we now already have a labor shortage. This leads to the observation that both push- and pull-factors exist. So far, only the factor sparking off migration is missing. Such factors could be the abolition of the visa requirement or the integration of the neighboring countries into EC development (which would mean that, as an EES country, we would have to allow the free migration of our neighboring countries' labor force).

Views have been expressed in Finland, according to which the recruiting of Estonian labor into our country should be especially favored:

»At least in joint ventures, labor force speaking Finnish and closely related languages might be available in the Soviet Union. This should be clarified. Because of their language and cultural background and their geographical proximity, Estonia and also the other Baltic countries and Eastern Karelia could be areas from where Finland could recruit labor for industry. The Finnish Employers' Confederation (STK) is endeavoring to promote this as much as possible. (Suomen Työnantajien Keskusliitto, kiertokirje 27. 11. 1989, 10)

Of the about 1.6 million persons living in Estonia, 600,000 are non-Estonian-born. If our country concentrates, for example, on favoring the immigration of Estonian labor, this will be of significance for the demographic development of Estonia, for two reasons. For one, the population of Estonia is small, so that immigration to Finland will be felt quite soon in the composition of the population, as immigrants usually concentrate in the 20-29-year-old age group. On the other hand, emigrating Estonian labor will most likely be compensated for in Estonia by labor of some other 
nationality. Estonia also has a labor shortage now, so that it is a desired migration destination in internal migration in the Soviet Union.

\section{Conclusions}

The European Community's free trade is supposed to be realized finally by the end of 1993. Up to that time limit, our country also has time to consider our own integration policy. Most likely, Finland will participate in integration development in EFTA's and the EC's joint organ, the EES. In practice, we will then accept the free movement of capital, goods, services and labor. Only foreign and security policy decision making will remain outside the sphere of future cooperation.

Internal migration in the European Community is now clearly more regulated than mobility between the Nordic Countries. It is a question of a difference of principle: in the Nordic Countries, mobility has always been based on the rights of everyman. In the EC, however, mobility mainly concerns the labor force and free mobility is seen as a prerequisite for economic growth. Migration between the countries in the Community is slight. Therefore, it can be assumed that, after 1992, migration from the various EC countries will only bring about a few hundred persons to Finland per year. On the other hand, migration from Finland will also grow only a little. This will mainly concern the migration of highly trained researchers, businessmen or representatives of the technical fields. These moves will be of specific length, so that in the long term they will benefit our country.

In the future, growing migration pressure will be directed toward Finland. The labor deficit arising in Finland cannot be satisfied exclusively by the very slight migration from the EC countries. The greatest desire to migrate to Finland will apparently come from our eastern neighbors, the Soviet Union and Poland, whose social situation favors large, sudden migration flows. The migration pressure from Estonia will endanger the development of Estonia's own economy and society. Finland should consider carefully means by which the economic development of Estonia could be promoted and, on the other hand, the labor force helped to remain where it is.

Very few studies have been made in our country on the relation between integration development and population questions. A study should be made, clarifying how much and what kind of migration pressure Finland's decreasing population development may possibly create in the future. What are the probable departing and arriving migration flows and the areas to which migration will be directed? What share of the future migration directed toward Finland will be made up by immigration from the EC countries? How will the migration coming to Finland from the countries of the European Community and from other countries differ from each other, demographically and regionally?

\section{References}

Andersen, Niels Ole (1988). Työvoiman vapaa liikkuvuus Pohjoismaissa ja Euroopan Yhteisön alueella (The free movement of labor in the Nordic countries and the European Community. Kööpenhamina: NAUT. Unpublished).

Cecchini, Paolo (1988). The European Challenge 1992. Brookfield: Gower Publishing Company. 
EVA (1988). Kurssi muuttuu: raportti alueellisista uhkista ja mahdollisuuksista (The course is changing: a report on local threats and possibilities). Helsinki: EVA, The Council of Economic Organizations in Finland.

ILO (1989). Informal Consultation Meeting on Migrants from NON-EEC Countries in the Single European Market after 1992. Geneva, 27-28 April 1989. Geneva: International Labour Office.

Lahti, Ari (1989). Macroeconomic Effects of European Integration on the Finnish Economy. A simulation Study. Suomen Pankin keskustelualoitteita 37/1989. Helsinki: Suomen Pankki. Unpublished.

Lumijärvi, Tarja (1990). Euroopan yhdentyminen ja aluepolitiikka. (European integration and regional policy). Sisäasiainministeriö, aluepoliittisia tutkimuksia ja selvityksiä N:o 3/1990. Helsinki: Sisäasiainministeriö.

Lundborg, Per (1989). Työvoiman vapaan liikkumisen seuraukset Ruotsin ja EC:n välillä (The consequences of the free movement of labor between Sweden and EC). Tukholma. Unpublished.

Molle, Willem and van Mourik, Aad (1988). International movements of labour under conditions of economic integration: the case of Western Europe. Journal of Common Market Studies 26 (3): 317339.

Muistio (Memorandum) 15. 9. 1989/TT. Työvoimaministeriö. Unpublished.

Nordisk Ministerråds Sekretariat (1988). Rapport fra Nordisk Arbejdsmarkedsudvalg (NAUT) om Norden og EF (Report from NAUT on the Nordic Countries and EC). Kobenhavn.

Parviainen, Seija (1989). Työllisyystavoitteet Euroopan yhteisön talouspolitiikassa (Employment goals in the economic policy of the European Community). Taloudellinen suunnittelukeskus, selvitys 28. Helsinki.

Séché, Jean-Claude (1988). A guide to working in a Europe without frontiers. Brussels: Commission of the European Communities.

Straubhaar, Thomas (1984). The accession of Spain and Portugal to the EC from the aspect of the free movement of labour in an enlarged common labour market. International Migration 22 (3): 228 - 238.

Straubhaar, Thomas (1987). Freedom of movement of labour in a common market. Efta Bulletin (4): $9-12$.

Suomen Työnantajain Keskusliitto (Finnish Employers' Confederation) (1989). Kiertokirje: Ulkomainen työvoima. 27. 11. 1989. (Circular: foreign labor. 27. 11. 1989). Helsinki. Unpublished.

Työvoimaministeriö, Suunnitteluosasto (Ministry of Labour, Planning Secretariat) (1988). Työmarkkinoiden tulevaisuus: Työvoiman kysyntä vuoteen 1995 ja tarjonta vuoteen 2000 (Future of the labor market: demand on labor until 1995 and supply until 2000). Työvoimapoliittisia tutkimuksia Nro 73, 1988. Helsinki: Työvoimaministeriö.

Valtioneuvoston tiedonanto Eduskunnalle Suomen suhtautumisesta Länsi-Euroopan yhdentymiskehitykseen (1989). (Government notice to the Parliament on the attitude of Finland to the West-European integration. Helsinki 28. 11. 1989. 